\title{
Does Knowledge Translate into Action? Impact of Perceived Environmental Knowledge on Ecologically Conscious Consumer Behavior
}

\author{
Manoj Das', Mahesh Ramalingam² \\ ${ }^{1}$ Department of Marketing, Institute of Management Technology, Hyderabad, India \\ ${ }^{2}$ Department of IT \& Analytics, Institute of Management Technology, Hyderabad, India \\ Email: manoj_nair@imthyderabad.edu.in, mahesh@imthyderabad.edu.in
}

How to cite this paper: Das, M. and Ramalingam, M. (2019) Does Knowledge Translate into Action? Impact of Perceived Environmental Knowledge on Ecologically Conscious Consumer Behavior. Theoretical Economics Letters, 9, 1338-1352. https://doi.org/10.4236/tel.2019.95087

Received: April 4, 2019

Accepted: June 11, 2019

Published: June 14, 2019

Copyright $\odot 2019$ by author(s) and Scientific Research Publishing Inc. This work is licensed under the Creative Commons Attribution International License (CC BY 4.0).

http://creativecommons.org/licenses/by/4.0/ (c) (i) Open Access

\begin{abstract}
In recent years, researchers have devoted considerable attention towards understanding how people perceive green/eco-friendly products and their behavioral patterns. In fact, millennials are more concerned with issues like global warming and environmental issues and are increasingly taking into account the impact of their product choices on environment. The present study aims to address whether perceived environmental knowledge translates into action and the role of price fairness and environmental concern between Perceived Environmental Knowledge and Ecologically Conscious Consumer Behavior. Data for that study were obtained through self-administered questionnaire from business school students (192 responses). Partial Least Square Structural Equation Modeling (PLS-SEM) approach was employed to analyze the data. The findings revealed that consumer with high and average environmental concern has increased level of Ecologically Conscious Consumer Behavior compared to consumer with low level of environmental concern. Hence, our study provides critical insights for action to policymakers and corporates for designing their communication strategies for succeeding in the indigenous Indian context.
\end{abstract}

\section{Keywords}

Price Fairness, Environmental Concern, Perceived Environmental Knowledge, Ecologically Conscious Consumer Behavior, PLS-SEM

\section{Introduction}

With the rapid rise of green consumerism, firms are making conscious efforts for implementing strategies aimed at minimizing the environmental impact as- 
sociated with their service offerings [1]. It has also translated into benefits for companies in terms of cost savings, new market opportunities, enhanced brand image and customer loyalty [2] [3]. Although such studies have been abundant in developed economies they are still at infancy stage in developing markets which offer their own unique complexities with researchers calling for further studies [4] [5]. [6] has defined socially conscious consumer as "a consumer who takes into account the public consequences of his or her private consumption or who attempts to use his or her purchasing power to bring about social change" (p. 188).

Environmental problems and issues have been gaining prominence and debated extensively over the last few decades with majority of respondents from all over the world indicating that environmental issues are a cause of concern for them [7] [8]. They have realized the seriousness of issues such as environmental degradation, climate change etc. translating into ecologically conscious behavior fuelled by a desire to buy eco-friendly products and services, favoring businesses that prefer environmental practice [9] [10] [11].

Evidence indicates that large numbers of consumers are now willing to pay for green products [12] [13]. In fact, a recent [14] report has pointed out that energy consumption and associated emissions can be reduced globally by modifying consumption patterns, using energy savings measures, and reducing food wastage. However, one area which has not received attention is the link between Perceived environmental knowledge (PEK) and Ecologically Conscious Consumer Behavior (ECCB) (Figure 1). Although companies are trying to bank upon this green products trend and coming up with products their success rate has been far from desirable [15]. So, although there are claims of people caring for environment why is it not translating into action? Some possible reasons could be their higher prices or the inability of people to understand its benefits [16] [17]. We believe that Price Fairness (PF) mediates this relationship and there is a moderation effect between Perceived Environmental Knowledge (PEK) and Price Fairness (PF) by Environmental Concern (EC). The article is organized as follows; we start with a brief literature review of all the relevant concepts and formulate our arguments for the hypothesis. This is followed by description of the research methodology which describes the data collection procedure, data analysis and results in detail, followed by discussion and limitation, future research scope .

\section{Environmental Concern (EC)}

Environmental concern is the fundamental pillar on which consumer environmental research is based [18]. A basic agreement regarding the meaning of the term is that it refers to how conscious are people regarding issue related to environment and how willing are they to address such issues reflecting their attitude towards environment protection [19] [20]. Evidence indicates that environmental concern significantly impacts consumers attitude towards green products 


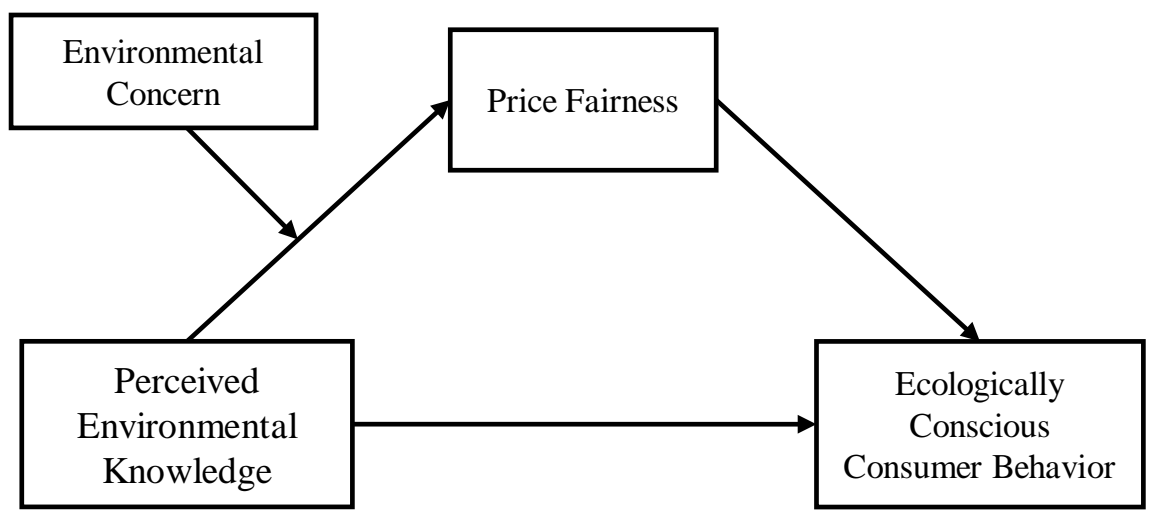

Figure 1. Conceptual model.

[21] thereby having an influence on their intention of purchasing such products [22] [23]. Individual's level of environmental concern is reflected in his inclination to behave in Ecologically Conscious Consumer Behavior (ECCB) [10] [24]. In fact [25], that recycling behavior among individuals was based on strength of the attitude thereby further strengthening our argument that environmental concern would result in ECCB. Hence such concerned consumers are more likely to were more likely to buy eco-friendly products to confirm their commitment towards environment [26].

\section{Price Fairness (PF)}

In case of individuals who are price and value conscious, if the reward/benefit sought after purchase is in future it has a negative influence on purchase intention [27]. Usually in the case of green products the benefits are realized at a point in time in future [28]. Price fairness has been identified as one psychological factor that exerts an important influence on consumers' reactions to prices (e.g. [29] [30] [31]). Fairness is a decision based on the significance of the value derived from a given product or service, whereas value is simply an assessment between the amount paid and some conception about quality which may be based upon either the buyer's reference price or their willingness to pay [32]. For example a value based consumer would prefer normal vegetables/lentils instead of organic vegetable/lentils free from pesticides due to his value consciousness. Fairness has been conceptualized as "a judgment of whether an outcome and/or the process to reach an outcome are reasonable, acceptable, or just" [33]. Consumers usually form an acceptable price range in their minds on the basis of their previous transaction and consider any deviation from this range as unfair [34] [35]. Evidence from previous studies indicates that consumers attach importance to price fairness and don't accept ranges considered unfavorable by them (e.g. [30] [31] [36] [37]). In fact they look for causality and try to understand why this has happened [38] [39]. Since green products are priced higher in comparison to their non-green alternatives, consumers' perceptions of the value they offer might be less in the short run [17] [28]. However, the total utility of 
green products may appeal to consumers with an enhanced sense of environmental and social consciousness.

\section{Ecologically Conscious Consumer Behavior (ECCB)}

Usually the purchase behavior of individuals is based upon an assessment of the benefits and costs which are of immediate significance solely to him, whereas in contrast, individuals exhibiting environmentally conscious behavior have a more future-oriented outcome (e.g. cleaner environment) which would benefit the society [19] [40]. According to [41], "ecologically conscious consumers are defined as those who purchase products and services which they perceive to have a positive (or less negative) impact on the environment". In fact they have further argues that both policymakers and marketers need to have a clear understanding of factors which might promote pro environmental behaviors.

\section{Perceived Environmental Knowledge (PEK)}

Perceived environmental knowledge (PEK) has been conceptualized as one's mental ability of understanding issues relate to environment or sustainability primarily related to pollution of air and water, using energy efficiently and conserving it and the impact of these on society and physical environment at par [22] [42] [43] [44]. Previous studies have found that attaining increased level of environmental knowledge leads to pro-environmental behavior which significantly affects consumers' intention to buy green products [45] [46]. In the context of emerging economies, few studies have found that perceived environmental knowledge may have a direct relation with favorable attitude towards green products which further effects on purchase intention for such products [22] [42] [47]. [48] have found that knowledge about environmental issues among university students influences their pro-environmental intention and behavior.

Based upon the literature review above, we can postulate the following hypothesis:

Hypothesis 1: There exists a positive relationship between Perceived Environmental Knowledge and Ecologically Conscious Consumer Behavior.

Hypothesis 2: The relationship between Perceived Environmental Knowledge and Ecologically Conscious Consumer behavior is mediated by price fairness.

Hypothesis 3: The relationship between Perceived environmental knowledge and price fairness is moderated by Environmental Concern.

Hypothesis 4: Price fairness moderates the strength of the mediated relationship between Perceived Environmental Knowledge and Ecologically Conscious Consumer behavior via Environmental Concern.

\section{Methodology}

The cross-sectional data were obtained through self-administered questionnaire from business school students in Hyderabad. The reason for selecting business school students is that today youth have become more concerned about the im- 
pact of their choices. We followed convenience sampling for collecting the data. Although there are concerns regarding the generalizability of results of convenience sampling researchers such as Cheah and [49] [50] have confirmed that students represent the ideal sample for such studies. The survey questionnaire includes study variables using established scales published in top journals and few demographics like age, gender and income. A total of 192 usable responses were obtained for an overall response rate of $76.8 \%$. Of respondents, $36 \%$ female and $64 \%$ male, the average age is 22 and the average income is 12 lakhs.

\section{Measures}

This study used the measurement scales which have been previously validated in available literature. Perceived Environmental Knowledge (PEK) was measured by four-item instrument based on the research of [44], Environmental Concern (EC) was measured by four items instrument based on the research of [51]. Environmental Conscious Consumer Behavior (ECCB) was measured by 12 -item instrument based on the research of [41] original 30-item ECCB scale. Price Fairness (PF) was measured by three-item instrument based on the research of [52]. All items were measured by a seven-point Likert scale, where 1 denoted strongly disagree, and 7 denoted strongly agree. The study used gender, age, family income as control variables. PROCESS macro used to estimate the indirect effects using bootstrap samples (5000 resamples) using $95 \%$ confidence interval. The reliability and validity of the measurement scales are shown in Table 1.

\section{Results}

In this study, the measurement and structural models were evaluated using the Partial Least Square Structural Equation Modeling (PLS-SEM) using SmartPLS 3.2.7 statistical software package [53]. The moderated mediation model is tested using Process macro 3.2 with 5000 Bootstrap Samples recommended by [54]. The rationale behind using PLS-SEM over covariance-based SEM is because of the following advantages [55] [56] [57]: 1) major focus on theory development 2) ability to handle smaller sample size (192 observations) and 3) capability of handling non-normal data. The effect of control variables (gender, age, family income) used in the study is not statistically significant. Hence, the results of control variables are not presented in the paper.

\section{Measurement Model}

The measurement model was evaluated based on the factor loadings, Cronbach's alpha, composite reliability, average variance extracted (AVE), discriminant validity using Fornell-Larcker Criterion [58]. The result of measurement model is presented in Table 2 and Figure 2 showed that all items in the study variables properly loaded and statistically significant with 5000 bootstrap samples [59] [60]. The Cronbach's alpha and the composite reliability values are range from 
Table 1. Summary of discriminant validity Fornell-Larcker criterion.

\begin{tabular}{lcccc}
\hline & $(1)$ & $(2)$ & (3) & (4) \\
\hline (1) Environmental Concern & $\mathbf{0 . 7 4 2}$ & & & \\
(2) Ecologically Conscious Consumer Behavior & 0.104 & $\mathbf{0 . 7 2 4}$ & & \\
(3) Perceived Environmental Knowledge & -0.042 & 0.425 & $\mathbf{0 . 7 5 4}$ & \\
(4) Price Fairness & -0.160 & 0.320 & 0.199 & $\mathbf{0 . 9 1 1}$
\end{tabular}

Note: Diagonal values are square root of AVE and off the diagonal values correlations among latent constructs.

Table 2. Summary of factor loading, Cronbach's alpha, composite reliability, average variance extracted (AVE).

\begin{tabular}{|c|c|c|c|c|c|}
\hline Construct & Items & Loadings & CA & CR & AVE \\
\hline \multirow{4}{*}{$\begin{array}{l}\text { Environmental Concern } \\
\text { (EC) }\end{array}$} & $\mathrm{EC} 1$ & 0.453 & \multirow{4}{*}{0.808} & \multirow{4}{*}{0.820} & \multirow{4}{*}{0.550} \\
\hline & $\mathrm{EC} 2$ & 0.719 & & & \\
\hline & EC3 & 0.995 & & & \\
\hline & $\mathrm{EC} 4$ & 0.699 & & & \\
\hline \multirow{12}{*}{$\begin{array}{c}\text { Ecologically Conscious } \\
\text { Consumer Behavior } \\
\text { (ECCB) }\end{array}$} & ECCB1 & 0.667 & \multirow{12}{*}{0.832} & \multirow{12}{*}{0.867} & \multirow{12}{*}{0.524} \\
\hline & ECCB10 & 0.556 & & & \\
\hline & ECCB11 & 0.569 & & & \\
\hline & ECCB12 & 0.213 & & & \\
\hline & ЕССВ2 & 0.574 & & & \\
\hline & ECCB3 & 0.649 & & & \\
\hline & ECCB4 & 0.576 & & & \\
\hline & ECCB5 & 0.713 & & & \\
\hline & ECCB6 & 0.546 & & & \\
\hline & ECCB7 & 0.762 & & & \\
\hline & ECCB8 & 0.680 & & & \\
\hline & ЕССВ9 & 0.562 & & & \\
\hline \multirow{5}{*}{$\begin{array}{l}\text { Perceived Environmental } \\
\text { Knowledge (PEK) }\end{array}$} & PEK1 & 0.674 & \multirow{5}{*}{0.813} & \multirow{5}{*}{0.867} & \multirow{5}{*}{0.568} \\
\hline & PEK2 & 0.717 & & & \\
\hline & PEK3 & 0.849 & & & \\
\hline & PEK4 & 0.773 & & & \\
\hline & PEK5 & 0.745 & & & \\
\hline \multirow{3}{*}{ Price Fairness $(\mathrm{PF})$} & PF1 & 0.853 & \multirow{3}{*}{0.897} & \multirow{3}{*}{0.936} & \multirow{3}{*}{0.829} \\
\hline & PF2 & 0.950 & & & \\
\hline & PF3 & 0.926 & & & \\
\hline
\end{tabular}

Note: $\mathrm{CA}=$ Cronbach's Alpha, $\mathrm{CR}=$ Composite Reliability, $\mathrm{AVE}=$ Average Variance Extracted. 


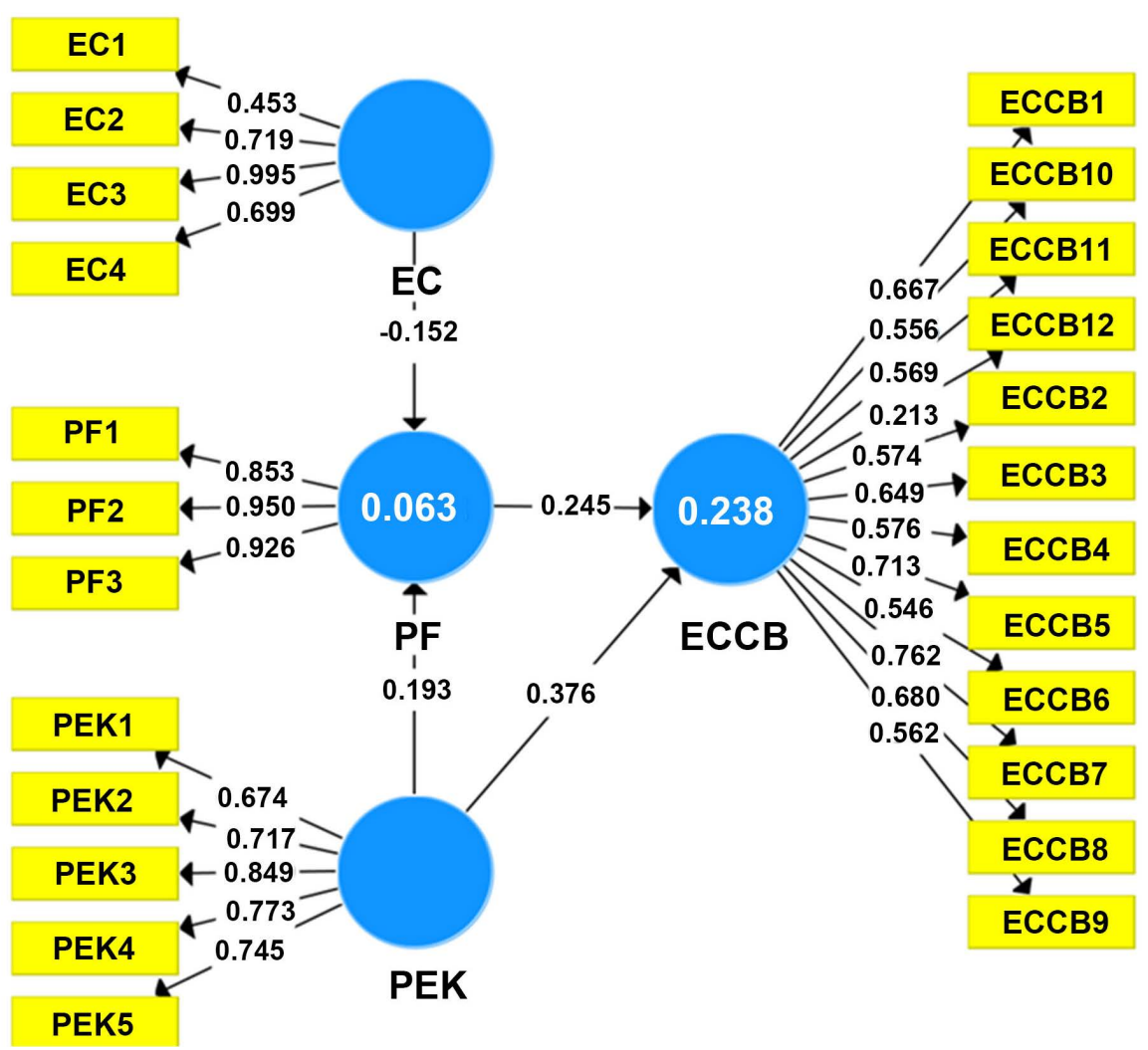

Figure 2. Measurement Model. Note: $\mathrm{EC}=$ Environmental Concern, $\mathrm{PF}=$ Price Fairness, ECCB = Ecologically Conscious Consumer Behavior, PEK = Perceived Environmental Knowledge.

0.808 to 0.936 and The AVE values of latent constructs are greater than 0.5 which proved the reliability of the latent constructs [61]. Fornell-Larcker Criterion discriminant validity presented in Table 1 shows that all the diagonal values (square root of AVE) are greater than off the diagonal values (correlations), which establishes the discriminant validity among latent constructs [62].

\section{Structural Model}

The structural model was evaluated using the path coefficient, coefficient of determination $\left(\mathrm{R}^{2}\right)$ effect size $\left(\mathrm{f}^{2}\right)$, predictive relevance $\left(\mathrm{Q}^{2}\right)$. Table 3 shows the results of structural model evaluation, which implies that all the direct relationships are statistically significant except the relationship between Environmental Concern and Price fairness. Hence, the first hypothesis that there exists a positive relationship between Perceived environmental knowledge $(\beta=0.376$ at $\mathrm{P}<$ 0.01 significance level) and Ecologically Conscious Consumer Behavior holds true. The coefficient of determination $R^{2}$ values for price fairness $\left(R^{2}=0.078\right)$ and Ecologically Conscious Consumer Behavior $\left(\mathrm{R}^{2}=0.27\right)$ are reported. In addition, the Structural Model evaluation showed satisfactory predictive relevance $\mathrm{Q}^{2}$ (Ecologically Conscious Consumer Behavior $=0.073$ and Price Fairness $=$ 0.043 ) and effect size $\mathrm{f}^{2}$ (Environmental Concern $=0.025$ and Perceived Environmental Knowledge $=0.040$ ) [58]. Finally, the overall model fit is evaluated 
Table 3. Moderated mediation analysis with environmental concern as a moderator between perceived environmental knowledge and ecologically conscious consumer behavior.

\begin{tabular}{|c|c|c|c|c|c|c|}
\hline \multicolumn{7}{|c|}{ Prediction of Price Fairness (Mediator) } \\
\hline & B & se & $\mathrm{t}$ & $\mathrm{P}$ & LLCI & ULCI \\
\hline PEK & 0.377 & 0.119 & 3.154 & 0.002 & 0.141 & 0.612 \\
\hline EC & -0.002 & 0.09 & -0.024 & 0.981 & -0.18 & 0.175 \\
\hline $\mathrm{PEK}^{\star} \mathrm{EC}$ & 0.338 & 0.126 & 2.679 & 0.008 & 0.089 & 0.586 \\
\hline \multicolumn{7}{|c|}{ Model Summary: $\mathrm{R}$ square $=0.078, \mathrm{f}$ value $=5.288, \mathrm{P}<0.05$} \\
\hline \multicolumn{7}{|c|}{ Prediction of Ecologically Conscious Consumer Behavior (Dependent Variable) } \\
\hline & B & se & $\mathrm{t}$ & $\mathrm{P}$ & LLCI & ULCI \\
\hline PEK & 0.416 & 0.067 & 6.173 & 0 & 0.283 & 0.549 \\
\hline $\mathrm{PF}$ & 0.169 & 0.04 & 4.212 & 0 & 0.09 & 0.248 \\
\hline
\end{tabular}

Model Summary: $\mathrm{R}$ square $=0.27$, $\mathrm{f}$ value $=34.78, \mathrm{P}<0.001$

Note: $\mathrm{EC}=$ Environmental Concern, $\mathrm{PF}=$ Price Fairness, $\mathrm{ECCB}=$ Ecologically Conscious Consumer Behavior, $\mathrm{PEK}=$ Perceived Environmental Knowledge, $\beta=$ Standardized Beta Coefficient, $\mathrm{se}=$ Standard Error, $\mathrm{t}$ $=\mathrm{t}$ Statistics, $\mathrm{P}=$ Probability Value, $\mathrm{LLCI}=$ Lower Limit Confidence Interval, ULCI $=$ Upper Limit Confi dence Interval.

using standardized root mean square residual (SRMR) value [63]. SRMR value of closer to zero indicates a perfect model fit, SRMR value of the present study is 0.084 indicating a good fit [64]. This section examines the importance of brand image and satisfaction to build the long-term relationship with the travelers. Heterogeneity is the major concern for applying different techniques in service research. To address this issue, we used Classification and Regression Tree Approach (CART), to ensure the robustness of the research model. To ensure the robustness of the research model the Classification and Regression Tree Approach (CART) is used identify the unobserved heterogeneity in the homogeneous sample [65]. CART methodology identified key variables to predict the Ecologically Conscious Consumer Behavior is environmental concern which divide the sample into two groups $(\mathrm{G} 1=102$ and $\mathrm{G} 2=90)$. The profiling of these groups can help us the get deeper understanding of data and the relationship between endogenous and exogenous variables.

\section{Moderated Mediation Analysis}

The moderated mediation model was analyzed using the PROCESS macro in IBM SPSS [54] for estimating the direct and indirect effects of Perceived environmental knowledge on Ecologically Conscious Consumer Behavior mediated by price fairness and moderated by Environmental Concern [54] Model 7. To evaluate the statistical significance of mediation and moderation effect $95 \%$ bias-corrected 5000 bootstrap samples were used. The results of moderated mediation model with direct effect conditional indirect effect and index of moderation 
mediation is presented in Table 1 and Figure 3.

The simple mediation analysis depicted above proves that there is a mediating effect of price fairness $(\beta=0.416$ at $\mathrm{P}<0.01$ significance level) between perceived environmental knowledge and Environmental Conscious Consumer Behavior leading to acceptance of hypothesis 2 which states that the relationship between Perceived Environmental Knowledge and Ecologically Conscious Consumer Behavior is mediated by price fairness. Similarly, the study showed the moderating effect of environmental concern $(\beta=0.416$ at $\mathrm{P}<0.05$ significance level with 0.035 Change in $\mathrm{R}^{2}$ ) between perceived environmental knowledge and price fairness. Hence, hypothesis 3 which states that the relationship between Perceived environmental knowledge and price fairness is moderated by Environmental Concern is accepted. Finally, the study concluded that there is a partial moderated mediation effect $(\beta=0.057, \mathrm{LCL}=0.006, \mathrm{UCL}=0.135)$ between perceived environmental knowledge and environmental conscious consumer behavior which prove the hypothesis 4 Price fairness moderates the strength of the mediated relationship between Perceived Environmental Knowledge and Ecologically Conscious Consumer Behavior via Environmental Concern. The conditional indirect (Table 4) shows that the moderation effect is holding true at mean level and high level of environmental concern.

\section{Discussion}

The present study examined the relationship between Perceived Environmental Knowledge and Ecologically Conscious Consumer Behavior mediated by price fairness. We also tested for the moderation effect of environmental concern between the Perceived Environmental Knowledge and price fairness.to the best of our knowledge no previous study has established these linkages. The study identified that consumer with high and average environmental concern has increased level of Ecologically Conscious Consumer Behavior compared to consumer with low level of environmental concern. Also, since our study has been done in Indian context hence it offers greater insights for companies regarding consumer behavior. The results of this study substantiate that all the proposed hypothesized relationships hold true.

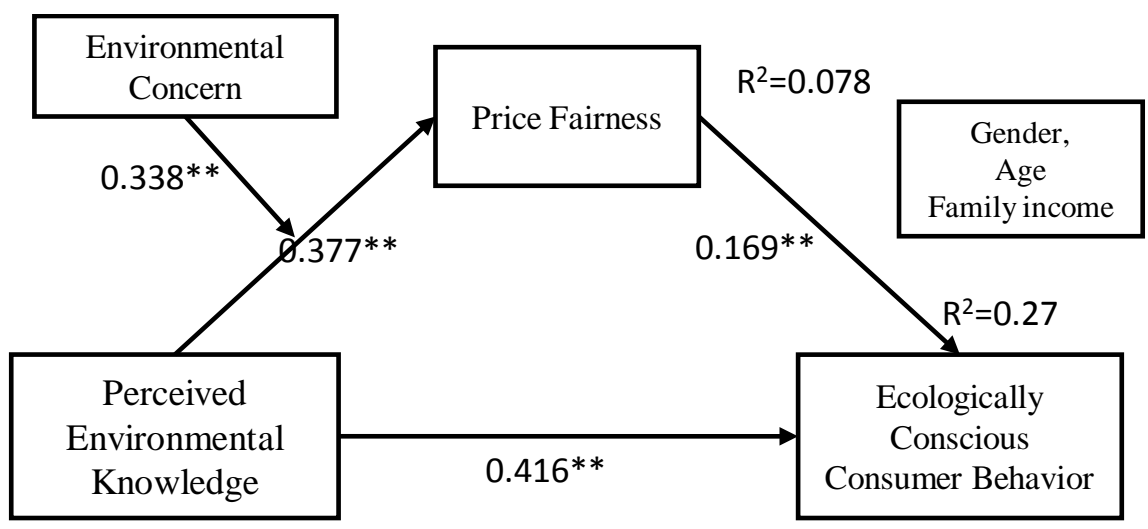

Figure 3. Moderated mediation model with estimates. 
Table 4. Direct Effect, Conditional Indirect Effect and index of moderated mediation.

\begin{tabular}{clccc}
\hline & Effect & Boot SE & Boot LLCI & Boot ULCI \\
\hline Direct Effect & 0.416 & 0.067 & 0.283 & 0.549 \\
\hline & \multicolumn{4}{c}{ Conditional Indirect effect } \\
\hline Environmental Concern $_{\text {Low }}$ & 0.01 & 0.035 & -0.063 & 0.079 \\
Environmental Concern $_{\text {Mean }}$ & 0.064 & 0.028 & 0.017 & 0.122 \\
Environmental Concern $_{\text {High }}$ & 0.117 & 0.048 & 0.037 & 0.221 \\
\hline & Index of Moderated Mediation & & \\
\hline Environmental Concern & 0.057 & 0.033 & 0.006 & 0.135 \\
\hline
\end{tabular}

Today youth constitute the majority of Indian population who are more conscious about the effect of their activities on environment and want value for their money. Hence, efforts to increase perceived environmental knowledge should be emphasized by both corporates and policymakers through all their communication efforts.

\section{Limitations and Future Research}

This study has few limitations which can be addressed by future research. First the study is limited to a particular geographical area of India i.e. Hyderabad thereby limiting its generalization in the overall Indian context. Also, in spite of our best effort to include the most important variables that could possibly influence the relationship between Perceived Environmental Knowledge and Ecologically Conscious Consumer Behavior, there might be other indirect or intervening variables like green trust, perceived risk, etc., which could shed light on Ecologically Conscious Consumer Behavior formation. The cross-sectional data maybe an issue in generalizing the research findings hence; further studies should adopt longitudinal approach for capturing change in behavioral pattern over a period of time.

\section{Conflicts of Interest}

The authors declare no conflicts of interest regarding the publication of this paper.

\section{References}

[1] Maletič, M., Maletič, D., Dahlgaard, J.J., Dahlgaard-Park, S.M. and Gomišček, B. (2014) Sustainability Exploration and Sustainability Exploitation: From a Literature Review towards a Conceptual Framework. Journal of Cleaner Production, 79, 182-194. https://doi.org/10.1016/j.jclepro.2014.05.045

[2] Hur, W.-M., Kim, Y. and Park, K. (2013) Assessing the Effects of Perceived Value and Satisfaction on Customer Loyalty: A ‘Green' Perspective. Corporate Social Responsibility and Environmental Management, 20, 146-156. https://doi.org/10.1002/csr.1280

[3] Kang, S. and Hur, W.-M. (2012) Investigating the Antecedents of Green Brand Eq- 
uity: A Sustainable Development Perspective. Corporate Social Responsibility and Environmental Management, 19, 306-316. https://doi.org/10.1002/csr.281

[4] Biswas, A. and Roy, M. (2015) Leveraging Factors for Sustained Green Consumption Behavior Based on Consumption Value Perceptions: Testing the Structural Model. Journal of Cleaner Production, 95, 332-340. https://doi.org/10.1016/j.jclepro.2015.02.042

[5] Biswas, A. and Roy, M. (2015) Green Products: An Exploratory Study on the Consumer Behaviour in Emerging Economies of the East. Journal of Cleaner Production, 87, 463-468. https://doi.org/10.1016/j.jclepro.2014.09.075

[6] Webster Jr, F.E. (1975) Determining the Characteristics of the Socially Conscious consumer. Journal of Consumer Research, 2, 188-196.

https://doi.org/10.1086/208631

[7] Dunlap, R.E. and Mertig, A.G. (1995) Global Concern for the Environment: Is Affluence a Prerequisite? Journal of Social Issues, 51, 121-137. https://doi.org/10.1111/j.1540-4560.1995.tb01351.x

[8] Diekmann, A. and Franzen, A. (1999) The Wealth of Nations and Environmental Concern. Environment and Behavior, 31, 540-549.

https://doi.org/10.1177/00139169921972227

[9] Kalafatis, S.P., Pollard, M., East, R. and Tsogas, M.H. (1999) Green Marketing and Ajzen's Theory of Planned Behaviour: A Cross-Market Examination. Journal of Consumer Marketing, 16, 441-460. https://doi.org/10.1108/07363769910289550

[10] Laroche, M., Bergeron, J. and Barbaro-Forleo, G. (2001) Targeting Consumers who Are Willing to Pay More for Environmentally Friendly Products. Journal of Consumer Marketing, 18, 503-520. https://doi.org/10.1108/EUM0000000006155

[11] Moser, A.K. (2015) Thinking Green, Buying Green? Drivers of Pro-Environmental Purchasing Behavior. Journal of Consumer Marketing, 32, 167-175. https://doi.org/10.1108/JCM-10-2014-1179

[12] Kotchen, M.J. and Moore, M.R. (2008) Conservation: From Voluntary Restraint to a Voluntary Price Premium. Environmental and Resource Economics, 40, 195-215. https://doi.org/10.1007/s10640-007-9148-x

[13] Nielsen, N. (2014) Global Consumers Are Willing to Put Their Money Where Their Heart Is When It Comes to Goods and Services from Companies Committed to Social Responsibility.

http://www.nielsen.com/us/en/press-room/2014/global-consumers-are-willing-to-p ut-their-money-where-their-heart-is.html

[14] IPCC (2016) Intergovernmental Panel on Climate Change. https://www.ipcc.ch/news_and_events/docs/misc/160111_PR_AR5_Synthesis_Repo rt_language_versions_final.pdf

[15] Gleim, M. and Lawson, S.J. (2014) Spanning the Gap: An Examination of the Factors Leading to the Green Gap. Journal of Consumer Marketing, 31, 503-514. https://doi.org/10.1108/JCM-05-2014-0988

[16] Mahenc, P. (2007) Are Green Products Over-Priced? Environmental and Resource Economics, 38, 461-473. https://doi.org/10.1007/s10640-007-9084-9

[17] Olson, E.L. (2013) It's Not Easy Being Green: The Effects of Attribute Tradeoffs on Green Product Preference and Choice. Journal of the Academy of Marketing Science, 41, 171-184. https://doi.org/10.1007/s11747-012-0305-6

[18] Hines, J.M., Hungerford, H.R. and Tomera, A.N. (1987) Analysis and Synthesis of Research on Responsible Environmental Behavior: A Meta-Analysis. The Journal of 
Environmental Education, 18, 1-8. https://doi.org/10.1080/00958964.1987.9943482

[19] Kim, Y. and Choi, S.M. (2005) Antecedents of Green Purchase Behavior: An Examination of Collectivism, Environmental Concern, and PCE. Advances in Consumer Research, 32, 592-599.

[20] Van Liere, K.D. and Dunlap, R.E. (1981) Environmental Concern: Does It Make a Difference How It's Measured? Environment and Behavior, 13, 651-676. https://doi.org/10.1177/0013916581136001

[21] Mostafa, M.M. (2007) Gender Differences in Egyptian Consumers' Green Purchase Behaviour: The Effects of Environmental Knowledge, Concern and Attitude. International Journal of Consumer Studies, 31, 220-229. https://doi.org/10.1111/j.1470-6431.2006.00523.x

[22] Yadav, R. and Pathak, G.S. (2016) Young Consumers' Intention towards Buying Green Products in a Developing Nation: Extending the Theory of Planned Behavior. Journal of Cleaner Production, 135, 732-739. https://doi.org/10.1016/j.jclepro.2016.06.120

[23] Paul, J., Modi, A. and Patel, J. (2016) Predicting Green Product Consumption Using Theory of Planned Behavior and Reasoned Action. Journal of Retailing and Consumer Services, 29, 123-134. https://doi.org/10.1016/j.jretconser.2015.11.006

[24] Pickett, G.M., Kangun, N. and Grove, S.J. (1993) Is There a General Conserving Consumer? A Public Policy Concern. Journal of Public Policy \& Marketing, 12, 234-243. https://doi.org/10.1177/074391569101200208

[25] Vining, J. and Ebreo, A. (1992) Predicting Recycling Behavior from Global and Specific Environmental Attitudes and Changes in Recycling Opportunities. Journal of Applied Social Psychology, 22, 1580-1607. https://doi.org/10.1111/j.1559-1816.1992.tb01758.x

[26] Pires, A., Martinho, G., Ribeiro, R., Mota, M. and Teixeira, L. (2015) Extended Producer Responsibility: A Differential Fee Model for Promoting Sustainable Packaging. Journal of Cleaner Production, 108, 343-353. https://doi.org/10.1016/j.jclepro.2015.07.084

[27] Lichtenstein, D.R., Ridgway, N.M. and Netemeyer, R.G. (1993) Price Perceptions and Consumer Shopping Behavior: A Field Study. Journal of Marketing Research, 30, 234-245. https://doi.org/10.1177/002224379303000208

[28] Gleim, M.R., Smith, J.S., Andrews, D. and Cronin Jr., J.J. (2013) Against the Green: A Multi-Method Examination of the Barriers to Green Consumption. Journal of Retailing, 89, 44-61. https://doi.org/10.1016/j.jretai.2012.10.001

[29] Etzioni, A. (2010) The Moral Dimension: Toward a New Economics. Simon and Schuster, New York.

[30] Kahneman, D., Knetsch, J.L. and Thaler, R.H. (1986) Fairness and the Assumptions of Economics. The Journal of Business, 59, S285-S300. https://doi.org/10.1086/296367

[31] Kahneman, D., Knetsch, J.L. and Thaler, R. (1986) Fairness as a Constraint on Profit Seeking: Entitlements in the Market. The American Economic Review, 76, 728-741.

[32] Grewal, D., Monroe, K.B. and Krishnan, R. (1998) The Effects of Price-Comparison Advertising on Buyers' Perceptions of Acquisition Value, Transaction Value, and Behavioral Intentions. Journal of Marketing, 62, 46-59. https://doi.org/10.1177/002224299806200204

[33] Bolton, L.E., Warlop, L. and Alba, J.W. (2003) Consumer Perceptions of Price (Un) 
Fairness. Journal of Consumer Research, 29, 474-491.

https://doi.org/10.1086/346244

[34] Cockrill, A. and Goode, M.M. (2010) Perceived Price Fairness and Price Decay in the DVD Market. Journal of Product \& Brand Management, 19, 367-374.

https://doi.org/10.1108/10610421011068603

[35] Gielissen, R., Dutilh, C.E. and Graafland, J.J. (2008) Perceptions of Price Fairness: An Empirical Research. Business \& Society, 47, 370-389. https://doi.org/10.1177/0007650308316937

[36] Martins, M. and Monroe, K.B. (1994) Perceived Price Fairness: A New Look at an Old Construct. Advances in Consumer Research, 21, 75-78.

[37] Urbany, J.E., Madden, T.J. and Dickson, P.R. (1989) All's Not Fair in Pricing: An Initial Look at the Dual Entitlement Principle. Marketing Letters, 1, 17-25. https://doi.org/10.1007/BF00436145

[38] Folkes, V.S. (1988) Recent Attribution Research in Consumer Behavior: A Review and New Directions. Journal of Consumer Research, 14, 548-565. https://doi.org/10.1086/209135

[39] Weiner, B. (1985) An Attributional Theory of Achievement Motivation and Emotion. Psychological Review, 92, 548-573. https://doi.org/10.1037/0033-295X.92.4.548

[40] McCarty, J.A. and Shrum, L.J. (2001) The Influence of Individualism, Collectivism, and Locus of Control on Environmental Beliefs and Behavior. Journal of Public Policy \& Marketing, 20, 93-104. https://doi.org/10.1509/jppm.20.1.93.17291

[41] Roberts, D.W. (1996) Landscape Vegetation Modelling with Vital Attributes and Fuzzy Systems Theory. Ecological Modelling, 90, 175-184. https://doi.org/10.1016/0304-3800(95)00164-6

[42] Chan, R.Y.K. (2001) Determinants of Chinese Consumers' Green Purchase Behavior. Psychology \& Marketing, 18, 389-413. https://doi.org/10.1002/mar.1013

[43] Murphy, P.E. (2005) Sustainable Marketing. Business \& Professional Ethics Journal, 24, 171-198. https://doi.org/10.5840/bpej2005241/210

[44] Mostafa, M.M. (2006) Antecedents of Egyptian Consumers' Green Purchase Intentions: A Hierarchical Multivariate Regression Model. Journal of International Consumer Marketing, 19, 97-126. https://doi.org/10.1300/J046v19n02_06

[45] Rokicka, E. (2002) Attitudes toward Natural Environment: A Study of Local Community Dwellers. International Journal of Sociology, 32, 78-90. https://doi.org/10.1080/15579336.2002.11770256

[46] Mostafa, M.M. (2009) Shades of Green: A Psychographic Segmentation of the Green Consumer in Kuwait Using Self-Organizing Maps. Expert Systems with Applications, 36, 11030-11038. https://doi.org/10.1016/j.eswa.2009.02.088

[47] Kumar, B., Manrai, A.K. and Manrai, L.A. (2017) Purchasing Behaviour for Environmentally Sustainable Products: A Conceptual Framework and Empirical Study. Journal of Retailing and Consumer Services, 34, 1-9. https://doi.org/10.1016/j.jretconser.2016.09.004

[48] Vicente-Molina, M.A., Fernández-Sáinz, A. and Izagirre-Olaizola, J. (2013) Environmental Knowledge and Other Variables Affecting Pro-Environmental Behaviour: Comparison of University Students from Emerging and Advanced Countries. Journal of Cleaner Production, 61, 130-138. https://doi.org/10.1016/j.jclepro.2013.05.015

[49] Cheah, I. and Phau, I. (2011) Attitudes towards Environmentally Friendly Products: The Influence of Ecoliteracy, Interpersonal Influence and Value Orientation. Mar- 
keting Intelligence \& Planning, 29, 452-472. https://doi.org/10.1108/02634501111153674

[50] DelVecchio, D. (2000) Moving beyond Fit: The Role of Brand Portfolio Characteristics in Consumer Evaluations of Brand Reliability. Journal of Product \& Brand Management, 9, 457-471. https://doi.org/10.1108/10610420010351411

[51] Lee, K. (2008) Opportunities for Green Marketing: Young Consumers. Marketing Intelligence \& Planning, 26, 573-586. https://doi.org/10.1108/02634500810902839

[52] Campbell, M.C. (1999) Perceptions of Price Unfairness: Antecedents and Consequences. Journal of Marketing Research, 36, 187-199. https://doi.org/10.1177/002224379903600204

[53] Ringle, C.M., Wende, S. and Becker, J.-M. (2015) SmartPLS 3. Boenningstedt: SmartPLS.

[54] Hayes, A.F. (2017) Introduction to Mediation, Moderation, and Conditional Process Analysis: A Regression-Based Approach. Guilford Press, New York.

[55] Barroso, C., Carrión, G.C. and Roldán, J.L. (2010) Applying Maximum Likelihood and PLS on Different Sample Sizes: Studies on SERVQUAL Model and Employee Behavior Model. In: Esposito Vinzi, V., Chin, W., Henseler, J. and Wang, H., Eds., Springer Handbook of Partial Least Squares, Springer, Berlin,; [Heidelberg, 427-447. https://doi.org/10.1007/978-3-540-32827-8_20

[56] Chin, W.W. and Newsted, P.R. (1999) Structural Equation Modeling Analysis with Small Samples Using Partial Least Squares. Statistical Strategies for Small Sample Research, 1, 307-341.

[57] Hair, J.F., Ringle, C. and Sarstedt, M. (2011) PLS-SEM: Indeed a Silver Bullet. The Journal of Marketing Theory and Practice, 19, 139-152. https://doi.org/10.2753/MTP1069-6679190202

[58] Hair, J.F., Hult, G.T.M., Ringle, C.M., Sarstedt, M. and Thiele, K.O. (2017) Mirror, Mirror on the Wall: A Comparative Evaluation of Composite-Based Structural Equation Modeling Methods. Journal of the Academy of Marketing Science, 45, 616-632. https://doi.org/10.1007/s11747-017-0517-x

[59] Anderson, J.C. and Gerbing, D.W. (1988) Structural Equation Modeling in Practice: A Review and Recommended Two-Step Approach. Psychological Bulletin, 103, 411-423. https://doi.org/10.1037/0033-2909.103.3.411

[60] Hulland, J. (1999) Use of Partial Least Squares (PLS) in Strategic Management Research: A Review of Four Recent Studies. Strategic Management Journal, 20, 195-204. https://doi.org/10.1002/(SICI)1097-0266(199902)20:2<195::AID-SMJ13>3.0.CO;2-7

[61] Bagozzi, R. and Yi, Y. (1988) On the Evaluation of Structural Equation Models. Journal of the Academy of Marketing Science, 16, 74-94. https://doi.org/10.1007/BF02723327

[62] Fornell, C. and Larcker, D.F. (1981) Structural Equation Models with Unobservable Variables and Measurement Error: Algebra and Statistics. Journal of Marketing Research, 18, 382-388. https://doi.org/10.2307/3150980

[63] Henseler, J., Dijkstra, T.K., Sarstedt, M., Ringle, C.M., Diamantopoulos, A., Straub, D.W., Calantone, R.J., et al. (2014) Common Beliefs and Reality about PLS: Comments on Rönkkö and Evermann (2013). Organizational Research Methods, 17, 182-209. https://doi.org/10.1177/1094428114526928

[64] Hu, L.-T. and Bentler, P.M. (1998) Fit Indices in Covariance Structure Modeling: Sensitivity to Underparameterized Model Misspecification. Psychological Methods, 
3, 424-453. https://doi.org/10.1037/1082-989X.3.4.424

[65] Cirillo, C., Eboli, L. and Mazzulla, G. (2011) On the Asymmetric User Perception of Transit Service Quality. International Journal of Sustainable Transportation, 5, 216-232. https://doi.org/10.1080/15568318.2010.494231 